AUTHOR NOTE:

Dr Tom Gibbons

Sport \& Exercise Section

School of Social Sciences \& Law

Teesside University

Middlesbrough

TS1 3BA

UK

Email: t.gibbons@tees.ac.uk 


\section{FAN DEBATES ON ENGLISH NATIONAL IDENTITY SURROUNDING THE ALMUNIA CASE ${ }^{1}$}

\section{Abstract}

English' national identity has undergone significant challenges post-1945 which means this national construct has reached a point where its very nature is uncertain. The aim of this paper is to discuss debates between football fans regarding the possibility that the Spanish goalkeeper, Manuel Almunia, might have been chosen to represent the English national team due to becoming a naturalised British citizen in 2009. This is argued to be evidence that debates between football fans can be used to highlight contemporary 'anxieties' surrounding English national identity. The paper is based upon a qualitative discourse analysis of findings from a participant observation study conducted between June 2008 and September 2009 with members $(n=93)$ of a large online football fan community. It is concluded that the Almunia debate illustrates the impacts of globalisation, European integration and United Kingdom devolution processes on the fragile concept of English national identity in the early twenty-first century.

\section{Introduction}

In the 1990s the very existence of English national identity began to be challenged by the culmination of the following interrelated developments: the declining global power of the British Empire; advancing globalisation and European integration; and, the devolution of the UK. ${ }^{2}$ England has contained strongly felt regional and local identities at the expense of a clearly defined entity that can be separated from Britain. ${ }^{3}$

Up until the European Football Championships ('Euro 96') - the first major international football tournament to be held in Britain since the 1966 World Cup Finals 
- the preferred flag of the majority of fans of the English national football team had been the British Union flag. ${ }^{4}$ Yet pressure was put upon England to establish their own distinctive 'national' identity because they played Scotland for the first time in the group stages of a serious international football tournament. This meant that the British flag suddenly became redundant as it would symbolise the union between both nations, rather than their individual national characters. ${ }^{5}$ Euro 96 is also widely considered to be the time when the majority of English football fans supposedly 'reclaimed' the St George's Cross flag from a minority of far right political groups, such as the BNP and the National Front, who had monopolised its use in football and other areas of society throughout the 1970 s and 1980 s. $^{6}$

Weight is just one of numerous academics, journalists and politicians to have regarded the increasing use of the St George's Cross by football fans since Euro 96 as evidence of a supposed rise in a specifically 'English', rather than 'British', national consciousness. ${ }^{7}$ Although Robinson's essay specifically argues that English football should be regarded as a suitable means through which to study English national identity, she does not provide any empirical evidence to suggest that the heightened use of the St George's Cross is intended by English fans to represent a unified Englishness. ${ }^{8}$ In contradiction to Robinson's claims, there is also evidence from Abell, Condor, Lowe, Gibson and Stevenson to suggest that English football fans' articulations of support for the national team do not even necessarily represent their wider feelings of national sentiment. ${ }^{9}$ To date little empirical evidence has been used to substantiate the assertion that a coherent and specifically 'English' national identity is intended by all contemporary English football fans.

Euro 96 did little to help solidify a shared sense of 'Europeanness' in the minds of English football fans, as studies on English press reporting of the tournament have shown. ${ }^{10}$ According to Levermore and Millward, informal interactions between supporters of 'G14' football clubs in European competitions (such as the UEFA Champions League) have been more successful than other more official attempts to 
establish a European identity, ${ }^{11}$ or at least a European consciousness. ${ }^{12}$ Using evidence from fan contributions to e-zines (the equivalent of fanzines on the Internet), Levermore and Millward suggest that many fans of G14 clubs (they refer to Liverpool fans for the most part) interpret their team's position in the pan-European Champions League as more important than their team's position in national competitions like the English Premier League (EPL) or the FA Cup. As the authors indicate themselves, this is somewhat similar to what King suggested in his earlier book on football and European identity, The European Ritual. ${ }^{13}$

Maguire suggests that sport occupies a 'contested terrain' which is used to display multiple layers of identity and global flows are producing a number of unintended consequences relating to the diversification of links between sports and cultural identities. ${ }^{14}$ The responses to global culture highlighted by the practices of King's sample of Manchester United fans illustrate these 'countervailing trends' of diminishing contrasts between groups and increasing varieties amongst them. ${ }^{15}$

In addition, using the case of English-born footballers who have chosen to play for the Republic of Ireland national team, Holmes and Storey argued that 'people can be quite happy to swap and switch their national affiliations and therefore to at least some degree, their own national identities' and they add that 'these insights castfurther light on the multi-layered, dynamic, shifting and contingent nature of social identities'. ${ }^{16}$ Holmes and Storey have previously written about how in recent decades the Republic of Ireland national football team 'has included a significant number of players born outside Ireland'. ${ }^{17}$ These authors go on to conclude that 'the factors influencing players' decisions exist on a spectrum ranging from primarily cultural affinity at one end to primarily career-related on the other'. ${ }^{18}$ An example from the past is Mick McCarthy being the captain of the Irish national team, despite being English. ${ }^{19}$

Drawing upon discussions on e-zine message-board websites for Liverpool and Oldham Athletic fans in 2005, Millward found that non-English players in the EPL seemed only to gain what he terms 'notional' acceptance among English fans that was 
often subject to their performance on the pitch. ${ }^{20}$ The same seems to be the case with managers taking into account the evidence provided above. Millward suggested that,

the increasing number of non-national European players in local teams might be one way in which national stereotypes are being eroded and a cosmopolitan consciousness may be developing. ${ }^{21}$

This idea supports King's 'Europeanisation' thesis and Millward concludes, 'Outsiders, such as foreign players are easy targets for criticism because they are 'different'.' 22 What Millward refers to as 'true cosmopolitanism' might appear on the surface when it comes to English support for foreign players (and managers); yet underlying xenophobic attitudes still persist. ${ }^{23}$ Maguire has termed this anti-British reaction the 'Little Englander', which he defines as a 'strong defensive reaction to globalization processes, European integration, the pluralization of national culture and the assertiveness of the "Celtic fringe".'24

The aim of this paper is to provide evidence to support the argument that debates between football fans can be used to highlight what Aughey termed contemporary 'anxieties' surrounding English national identity which are more complex than the post96 rise in the use of the St George's Cross by English football fans suggests. ${ }^{25}$ In this paper debates between football fans concerning what became known as the Almunia Case' are regarded as a microcosm through which to observe some of the current 'anxieties' surrounding English national identity more broadly.

\section{The Almunia Case}

Manuel Almunia is a goalkeeper born in the Navarre region of Spain who signed for the EPL club Arsenal F.C in July 2004. In July 2009 he became eligible to gain British citizenship through naturalisation considering he had lived and worked in the UK for 
five consecutive years. As Almunia had never been called up to play international football for Spain before 2009, he had the option to play for England if picked by the England manager, Fabio Capello. ${ }^{26}$ As early as 2007 - but then more consistently from the summer of 2008 after England (and the other UK nations) had failed to qualify for Euro 2008, a tournament which the Spanish national team later went on to win - the English national press began to focus attention on the fact that Almunia had announced on a few separate occasions that he would like to play for England if he was given the chance, but that this was only if he was not called up by Spain first. ${ }^{27}$

In the spring of 2009 the Almunia case again became a hot topic in the English press because the goalkeeper had arguably just had his best season yet for Arsenal and this happened to coincide with the England national team competing in qualifiers for the 2010 World Cup under massive pressure from the English press and general public following the team's recent failures. This was equally fuelled by the choice of English goalkeepers becoming increasingly sparse at the time due to a number of injuries and some poor performances. ${ }^{28}$ The Almunia case is somewhat of an anomaly as whilst there are many past and present foreign EPL players who have remained in the UK long enough to be eligible for British citizenship; it is rare for such players to have never played international football considering their obvious talent. The only reason this is the case with Almunia is because there are two other goalkeepers who have kept him out of the Spanish national squad: Iker Casillas (Real Madrid) and Pepe Reina (Liverpool).

\section{Methodology}

This paper is based upon findings from a doctoral research project in which an online participant observation study was conducted. The online fan community or discussion forum within which the study was conducted was chosen specifically because of its independence from any single club, governing body or as sociation. 
The forum is an independent website created, maintained and for the use of football fans from all over the globe. The site was established in 2007 and remains active at the time of writing with well over 1,000 members, a figure that continues to grow.

The author joined the forum on 12 June 2008 and went on to make 204 posts, ${ }^{29}$ the final one being 12 September 2009. In total, 93 participants contributed to the 29 discussion threads that were used as data in the study. ${ }^{30}$ Whilst most of the sample was English (62\%) and it was their comments that provided the vast majority of the data, fans of other nationalities also contributed with some comments that were utilised as comparative data. The majority of this figuration of fans were male $(92 \%)$ and the age range was large (18-69 years; mean age $=30$ years). The author became a member of the online forum and actively contributed through posting new discussion topics as well as joining in existing discussion threads started by other users on a daily basis. ${ }^{31}$

Transcripts from discussions between fans were analysed using a coding approach termed 'qualitative discourse analysis'. Maguire and Poulton conducted such an analysis on English newspaper coverage of the Euro 96 football competition and focused upon the portrayal of English national identity. ${ }^{32}$ Practically, the qualitative discourse analysis used was similar to that suggested by Miles and Huberman. ${ }^{33}$ 'Codes', also referred to by Miles and Huberman as 'tags or labels for assigning units of meaning', ${ }^{34}$ were developed using a 'semi-inductive' coding technique. In what follows dominant codes are indicated by italicised sub-headings. Key extracts are used to demonstrate recurrent themes in the data.

\section{Discussion of Findings}

English fans were clearly divided on the Almunia case and their debates brought out a number of concerns relating to the construction and representation of English 
national identity around the English national football team which are discussed in the following sub-sections.

\section{Ethnic versus Civic}

Whereas some fans stated that Almunia's Spanish heritage meant he should not be permitted to play for any other country, others stated that if he was eligible to play for England through obtaining British citizenship it should not matter what his ethnic heritage is. This sparked interesting debate over what 'English' should actually be based upon: ethnicity or citizenship. For instance:

May 12009 10:17pm 35

6: ${ }^{36}$ I don't see what the problem is. Almunia will be getting British Citizen because of his treaty rights - i.e. because he's been self sufficient in Britain for more than five years. He works for his living and pays a lot of tax so I think if he's eligible, he's got as much right as any others to play for the country that he contributes to. Surely it's better to have a player who is good and who wants to play for England, rather than a third rate keeper who is preferred for no other reason than he happens to be born here. [Female, English, Leeds United FC, aged 24]

May 12009 10:21pm

18: Britain don't have a football team though (Fan 6) (smiley face emoticon). [Male, English, Juventus FC, aged 28]

May 12009 10:23pm

6: But he got his citizenship (or will get his citizenship) because he's been living and working in England specifically. 
60: Yeah but it's not English citizenship it's British. I don't like the idea, but tbh it wouldn't surprise me the way football is going. ${ }^{37}$ [Male, English, West Ham United FC, aged 45]

May 12009 10:33pm

6: Yes, but he gets it because he's been working in ENGLAND. Nobody has English citizenship. The likes of Wayne Rooney for example (b.1985), British by parents. Nobody is automatically British anymore. And nobody is an English citizen ever.

Fan 6 continued to push the legal entitlement to British citizenship as justification that Almunia should be allowed to play for England, often highlighting EU rules on citizenship rather than those of the UK. Thus fan 6 was displaying her preference for a more integrated European identity. Fan 18 disagreed and would simply not accept that British citizenship was enough to qualify Almunia as English. This was particularly interesting considering one of fan 18's parents was an Italian immigrant and so one might expect him to have a more inclusive, perhaps 'European-based' identity, in a similar fashion to the fans discussed by King; Levermore and Millward; and, Millward. ${ }^{38}$ Later on in the thread, fan 60 attempted to justify his defence of Englishness by declaring he was not British, only English. Fans 18 and 6 were keen to point out that whether he liked it or not, fan 60 was in fact a British citizen. The same kind of debate arose again in a later thread once it had been announced that Almunia was now eligible to gain British citizenship via naturalisation. Here fan 9 attempted to justify Almunia playing for England due to his substantial tax contributions to the British government:

July 122009 04:35pm

9: Almunia is now eligible for dual citizenship presumably, what more do you want? The guy has probably paid more into our country's tax system than I ever will in my life, he has therefore contributed more to this nation than I. [Male, English, Birmingham City FC, aged 24] 
In support of this, fan 6 repeated the same question she had raised in the previous thread regarding British citizenship being a justifiable criterion for Englishness. This met with opposition from fan 18, but support from others:

\author{
August 22009 06:12pm \\ 6: Okay then, forgetting about football for a second: do you think Almunia should be \\ allowed to have British citizenship? [Female, English, Leeds United FC, aged 24]
}

August 22009 06:15pm

18: Yes. And the answer to your next question is 'no', because he is therefore British and not English. [Male, English, Juventus FC, aged 28]

August 22009 06:18pm

6: Everybody in the English national team is British. And he got his citizenship by living in England. Much like people who are born British derive their English national mentality from spending their life here.

August 22009 06:22pm

18: Ok so if you went to Belgium and lived for two years, as is there requirement for citizenship, laughably, would you consider playing sport for their national side? Do you think that is right?

August 22009 06:24pm

6: Why not? If I could get a job for them. They are kind enough to let me live in their country, who am I to turn my nose up at representing them?

Both fans in the above discussion had different but equally valid conceptions of what English national identity should be based upon. This discussion highlights how resistance to both 'pluralization processes and the integrative tendencies associated 
with globalization reflects the ability of national cultures to be responsive to global flows'. ${ }^{39}$ These seemingly contrasting responses to the integrative processes at work within Europe that have allowed Almunia to become a British citizen via naturalisation, and as a result, be in a position where he could theoretically be picked to represent the English national team, are evidence of the diminishing of contrasts between national groups within Europe and the increasing varieties of expressions of identity that are simultaneously made possible..$^{40}$

\section{Talent versus Blood}

Related to the above, English fans were also divided over whether Almunia's talent should override the fact that he was not born in the UK and had no family links (or 'blood ties') to the nations within it. Comparisons were made between Almunia and 'foreign' players in other national teams such as the Republic of Ireland, Italy and Spain. Various cases of foreign players/athletes representing English national teams for other sports such as cricket and rugby were also raised with some fans stating football should be regarded differently to other sports and others contending that there was no difference.

The following are examples of English fans being negative about Almunia playing for England on the grounds that they did not consider him to be English even if he gained British citizenship because he was not born or raised in England:

May 12009 06:29pm

13: I only want England players playing and managing England, so it's a big no-no from me. [Male, English, Leeds United FC, aged 25] 
15: He's a good keeper l'll give him that but even with British citizenship he will still be Spanish so it's a no from me. [Male, English, Chelsea FC, aged 44]

May 12009 07:23pm

18: No, he is not English in any way. [Male, English, Juventus FC, aged 28]

May 12009 07:57pm

39: I don't think someone without ANY connection to English blood should be playing in the team. [Male, English, Liverpool FC, aged 36]

May 52009 03:34pm

60: Almunia is Spanish however ya (sic) look at it and doesn't have a trace of English bloody anywhere, I wouldn't like to see him in a England shirt, in fact I would hate it, it shows desperation in my opinion, so his (sic) not good enough for them but he is for us. Sorry but fuck that. [Male, English, West Ham United FC, aged 45]

The same fan later went on to add:

May 52009 04:26pm

60: He's been a servant to the country paid his taxes etc. .... But he's still Spanish at heart whether he's got British citizenship or not, ask the man when he gets it if he's English or Spanish he would say Spanish every time. I honestly would rather keep the team English rather than have a few foreign players who are deemed British as they have lived here however many years. I would rather be shite and 140th in the world but have an English side than be a top team in the world with a team with a few foreign players.

Some fans directly blamed the increased amount of non-English players in the EPL for threatening the very existence of national identification, which many felt national teams 'should' represent. For instance, when one fan stated: 
May 12009 09:02pm

24: what about if it was Torres and not Almunia? Just say Torres hasn't played for Spain and has been here five years so qualifies. How many wouldn't want Torres for England? ${ }^{41}$ [Male, English, Arsenal FC, aged 41]

Another was quick to respond:

May 12009 09:06pm

18: Interesting how the English sell-out mentality has crept from the clubs to the national teams. Scary really. Where's the pride in seeing a team of foreign players win a trophy for your country? What do people get out of that? Is winning all that counts? [Male, English, Juventus FC, aged 28]

In response to such comments, the author asked forum members the following two questions relating to foreign fans:

May 52009 03:28pm

1: This happens in other sports, athletics is a prime example with Kenyans running for various countries despite never setting foot in them, so why not in football? Also, English Premier League clubs no longer represent the localities in which they are based (foreign players, managers, owners and fans) so why should the national team?

To which Fan 18 was the first to reply with the following:

May 52009 03:32pm

18: I think football and other sporting teams are the last remaining media for fans to show national pride. But judging by some comments on here, it seems that the feeling is disappearing rather quickly. Perhaps due to the lack of success in particular in recent 
years. I can picture it now, England win the World Cup under Capello and it will be 'we are England, best team in the world, we don't need johnnies like Almunia in the team'. ${ }^{42}$ Oh ... [Male, English, Juventus FC, aged 28]

Here fan 18 highlights the hypocrisy surrounding support for the English national team on the basis of 'identity'. The Italian former manager of the England national team, Fabio Capello, proved a similarly controversial figure to Almunia in debates among English fans. Feelings towards Capello, the second non-English manager to manage the English national team, ${ }^{43}$ were discussed and fans were divided on whether the national identity of players representing England was different to or the same as that of managers. For instance:

May 12009 07:23pm

18: No, he is not English in any way. [Male, English, Juventus FC, aged 28]

May 12009 07:35pm

3: Nor is the manager. [Male, English, Arsenal FC, aged 53]

May 12009 07:38pm

18: A coach is different, any nationality can coach a side.

May 12009 07:39pm

12: Managers who manage a country and players who play for their country are miles apart. [Male, English, Tottenham Hotspur FC, aged 49, emphasis in original]

May 12009 07:45pm

3: Lost our identity already so it don't (sic.) matter.

May 52009 04:12pm 
60: I don't really like the idea of Capello but we have him there now so we have to lump it but I won't accept a Spanish player by birth and blood to be playing for the national team, there's one thing having a foreign manager but a player well l'm sorry that takes the piss, I couldn't give a fuck how long he has lived here ask him if he's Spanish or English he will say Spanish every time. This gets my blood boiling it really does. [Male, English, West Ham United, aged 45]

English support for Capello was surprisingly positive at this time because he was relatively new as England manager and because England were winning. However, there were some English fans who felt the national team no longer represented them due to having a foreign manager, for instance:

September 52008 11:48am

3: l'd never get behind them like at one time, England lost itself as soon as they put a Johnny in charge (popcorn eating emoticon). [Male, English, Arsenal FC, aged 53]

Then in a later thread the same fan wrote:

May 52009 03:49pm

3: lost our pride once a johnnie took charge.

During the Germany vs. England friendly match English fans were praising Capello, but this seemed to be only because England won the match:

November 192008 10:44pm

51: England looking a real outfit with Capello. Unrecognisable from team a year ago ... incredible what a class manager can do. [Male, English, Sporting Clube de Portugal FC, aged 35] 
November 192008 10:45pm

63: FT Capello we love you (emoticon flying St George Cross). ${ }^{44}$ Time to celebrate (emoticon holding a beer). [Male, English, Arsenal FC, aged 23]

The same fan later relayed similar sentiments when England beat Ukraine:

April 2009 10:00pm

63: KING CAPELLO (four emoticons with various St George Cross flags).

Regardless of the obvious contradictions regarding Capello and Almunia, many fans remained in opposition after the announcement was made that Almunia was eligible for British citizenship and some other members voiced their concerns:

Jul 132009 07:53pm

60: He can fuck off he's Spanish. End of. [Male, English, West Ham United FC, aged 45]

August 312009 01:20am

92: No I don't want a Spanish keeper in an England team it should be only for players born and brought up in England. Whoever thought of that idiotic idea? [Male, English, Tottenham Hotspur FC, aged 32]

September 152009 03:32am

70: Almunia is Spanish and although not being good enough to play for us, he would only consider playing for us as he is behind Casillas and Reina, who are still going to be playing when he retires. [Male, English, Liverpool FC, aged 24] 
Comparisons were made between the large contingent of foreign players in EPL clubs with some fans saying national teams will become like clubs and no longer represent nations. For example:

August 22009 06:02pm

18: Ok so you think that anyone can play for any country, I think that basically destroys international football. It just becomes like club football. National football teams are a source of national pride and attention, it would be a waste of time playing as England or Spain or whoever with a team full of foreign players, it becomes invalid in itself, it therefore isn't England or Spain it is just a football team. I blame this attitude on the club game becoming so dependent on foreign players. Also if the national team was good people would have more pride in it and wouldn't even entertain the idea, which in itself is a sad indication. [Male, English, Juventus FC, aged 28]

There were however, also English fans who said they would welcomeAlmunia into the England team regardless of his nationality due to him being a proficient goalkeeper. Most fans in this camp were Arsenal fans who simply wanted to see another Arsenal player in the English national team. For instance, the forum founder (an Arsenal fan) even began chanting for Almunia at one point:

July 132009 04:01pm

3: He's big, he's mean, he's better than Robert green Almunia Almuniaaaaaaaaaaa! (waving emoticon) [Male, English, Arsenal FC, aged 53]

In response to the apparent contradiction between this fan's previous xenophobic attitudes towards anything non-English, and his support for Almunia playing for his beloved England, the author asked: 
1: I thought you were fiercely patriotic about England? If he (Almunia) didn't play for Arsenal would you have a different view?

There was no response to this from fan 3 . This seemed to be a good example therefore both of the contingent nature of national identity for this fan and the hegemony of his support for Arsenal over his support for England..$^{45}$

Yet, this kind of 'Little Englander' viewpoint expressed by some could not accurately be applied to the views of all English fans ${ }^{46}$ Another fan contributing to this thread said of Manuel Almunia:

July 132009 07:59am

24: I don't think he is good enough for Arsenal let alone England. [Male, English, Arsenal FC, aged 41]

To which a different Arsenal fan responded:

July $1308: 27 \mathrm{pm}$

19: He'd definitely be first choice if he was allowed to play for England. I'm not trying to be funny or anything, but if you seriously watch his performance over the past two years he has greatly improved and he's a very good goalkeeper now. David James will always fuck up while Robert Green and Scott Carson aren't good enough at international level. Whether you agree with him playing for England or not, I don't think you can argue that he wouldn't be good enough to be first choice. [Male, English, Arsenal FC, aged 21]

Yet another English Arsenal fan later clearly highlighted that he had club over country concerns regarding Almunia playing for England also: 
63: In some ways I personally would kind of hope Almunia would at least play a friendly for England and do it well, just to try and change this silly attitude. On the other hand if he made the smallest of errors he would be lamb to the slaughter and though l'd rather Arsenal had a proper class keeper, he is our current and being targeted would be very unfortunate. [Male, English, Arsenal FC, aged 23]

There were also examples of other fans that were happy to have Almunia playing for England. For instance, a Birmingham city fan wrote:

May 52009 03:52pm

9: He's better than any of the English lads. Let him play, all the other countries do it FFS!47 Look at Zidane, Viera, Klose, Podolski, Deco, Senna ... I could go on. [Male, English, Birmingham City FC, aged 24]

Fan 9 also repeated this in response to Almunia actually becoming eligible for British citizenship whilst again adding that other national teams contain 'foreign' players so there is no reason why England should not do the same:

July 132009 04:05pm

9: I'd be happy for him to play for us. Why the fuck not, he's better than our current crop of shitters. Plus every other country does it, why shouldn't we? Look at the Brazilians in Portugal's team, or all the African born players in French teams over the years, or the polish players in the German side.

The post following this, from a Newcastle United fan, supported this view:

July 132009 04:06pm

38: I'm all for it ... other countries do it, why shouldn't we? [Male, English, Newcastle United FC, aged 33] 
However, these posts were met with a long riposte from fan 18 who felt it important to clarify the situation regarding 'foreign' players in other national teams stating that citizens of former colonised nations playing for the national teams of their 'mother' countries are different to those who simply switch nationality completely. Examples of other foreign players representing different national football teams were often provided by other fans. For instance, Fan 12 asked:

May 2009 07:57pm

12: Where would it end? We would end up like Ireland under Charlton ... a joke. [Male, English, Tottenham Hotspur FC, aged 49]

Fans were also divided as to whether Almunia - a person from another European nation gaining naturalisation as a British citizen - could be considered to be the same as, or whether he is entirely different to, a person with mixed heritage. Others were keen to indicate that Almunia would only choose to play for England because he did not get chosen to represent Spain and others seemed to disagree with this (apart from most Arsenal fans), for instance:

May 12009 06:43pm

29: I don't think l'd have a problem with it if it weren't for the fact that he'd obviously much rather play for Spain if he could. [Male, English, Blackburn Rovers FC, aged 21]

August 312009 02:33am

47: If Spain wanted him he'd never even consider playing for England, so why should we consider picking him? In principle l've got no problem [with] someone moving to England to settle, gaining nationality and deciding they want to represent the country. But Almunia is just a mercenary in this situation; you shouldn't be able to shop around to see what country you play for if your real one doesn't want you. Players should have 
to choose a country at age 21 out of the ones they qualify for and only be able to change that in exceptional circumstances. [Male, English, Queens Park Rangers FC, aged 24]

Almunia was often compared with Owen Hargreaves who had chosen to play for England due to his English parentage, despite having Canadian citizenship and the fact that his footballing skills were honed in the German Bundesliga rather than the EPL. Some fans suggested the Almunia case was no different to that regarding Hargreaves, for example:

May 12009 07:45pm

60: I don't like the idea but it's no different from Owen Hargreaves really. [Male, English, West Ham United FC, aged 45]

May 52009 03:44pm

6: I don't think it's a prerequisite to be English through and through. Owen Hargreaves' link to England is fairly tenuous when you consider he grew up in Canada, worked in Germany etc. At least Almunia lives and works in the country he could potentially be playing for. Hargreaves had six teams to choose from, LOL! You can't say he picked England because he felt deeply English! [Female, English, Leeds United FC, aged 24]

Whereas others disagreed and felt the Almunia and Hargreaves cases were totally different:

May 12009 07:53pm

47: Hargreaves qualified for several (through family) and chose England from the offset. Almunia qualified for Spain but they didn't want him, now he wants to play for someone else [Male, English, Queens Park Rangers FC, aged 24] 
May 12009 09:50pm

18: Hargreaves has ties to England ... Owen Hargreaves. Manuel Almunia. See the difference? (Smiley face emoticon). [Male, English, Juventus FC, aged 28]

May 52009 03:49pm

60: (Hargreaves) chose what's best for him but he had a selection opportunity through blood ties, what ties does Almunia have? [Male, English, West Ham United FC, aged 45]

September 122009 05:33pm

34: Hargreaves and Almunia are different cases imo. ${ }^{48}$ Both of Hargreaves' parents are English but they immigrated (sic.) to Canada. That's very different to gaining citizenship for living here long enough. [Male, English, Manchester United FC, aged 30]

Almunia's case was also compared with that of the Spanish player Nacho Novo who became eligible for British citizenship through playing in the Scottish Premier League (SPL) for eight years in October 2008. Novo considered playing for the Scottish national team as he had not been picked by Spain but had played for Galicia, a national team not formally recognised by FIFA (Fédération Internationale de Football Association). ${ }^{49}$ In response to this there was a supposed 'gentlemen's agreement' between the UK FAs that they would not pick 'foreign' players for their national teams. This was an issue raised by forum members and could well be the reason why a player without English heritage has never been picked for the national team. However, it was difficult to find any firm evidence that this agreement had actually been made and this is an area ripe for further research.

\section{Conclusion}


The findings of the current study highlighted how debates between football fans regarding the Almunia case went beyond football to reveal how contemporary English national identity is best described as 'multi-layered' and in a 'state of flux' characterised by advanced global (and European) interconnections, of which the Internet forum itself is an example. The Almunia case illustrated the contested nature of what constitutes Englishness and the fragility of this national construct.

Whereas some fans argued that 'blood ties' or birthplace should determine whether a player should be permitted to represent England by playing for the national football team, other fans argued that British citizenship gained through naturalisation was a sufficient criterion. There were also fans who stressed that talent should be the determining factor in selecting national teams regardless of actual nationality, as is the case in European club football. Discussions on the Almunia case seemed to reinforce previous research regarding foreign players in other national teams only gaining 'notional' acceptance by fans. ${ }^{50}$ Whilst Maguire's 'Little Englander' thesis was evident amongst some fans' reactions to the Almunia case, there were also other fans who seemed to accept the diminishing of contrasts that had occurred as a result of global flows such as European integration and the resultant increase in the number of possibilities/varieties this offered. ${ }^{51}$

Giulianotti and Robertson summarise that 'as labour markets have globalized, more complex differences arise in relation to the imported player, his club, its supporters, its home nation, and his national team'. ${ }^{52}$ This was certainly what has happened with regards to the Almunia case. Giulianotti and Robertson go on to stress how dual citizenship, naturalisation or even completely switching nationality 'already occurs in many other labour markets' outside football, but how football governing bodies are attempting to challenge this homogenising process. ${ }^{53}$ They highlight how UEFA and FIFA have already attempted to counter this possibility (or certainly limit it) by restricting the number of non-nationals in starting line-ups (reminiscent of the case prior to the Bosman ruling in 1995/6). FIFA regulations had previously allowed 
uncapped players to change national allegiance after living in their new nation for only two years. However, to tighten regulations, the 2008 FIFA Congress voted to raise the term to five years. ${ }^{54}$

These findings could also be partially explained by Giulianotti and Robertson's reconfiguration of Billig's concept of 'banal nationalism' into understanding how international football creates opportunities for 'exceptional nationalism'. ${ }^{55}$ This contradicts the more routinely experienced 'banal cosmopolitanism' that characterises contemporary social life according to these authors. However, as evidence for this assertion, Giulianotti and Robertson fail to go beyond citing the fact that national flags become 'suddenly ubiquitous' during international tournaments, whereas the evidence provided in the current study suggests the 'national' identity articulated by English fans is more multidimensional in nature than the ubiquitous display of the St George's Cross suggests. ${ }^{56}$

\section{Notes}

\footnotetext{
${ }_{1}$ Much of the content of this article has previously appeared in a book by the author titled: English National Identity and Football Fan Culture: Who Are Ya? Surrey: Ashgate, 2014. Copyright (C) Gibbons, 2014. Permission has been granted to re-use this work by Ashgate publishers.

2 Colley, Britons; Curtice; 'Is there an English Backlash?'; Kumar; The Making of English National Identity; McCrone, 'Who do you say you are?'; McCrone, 'A nation that dares not speak its name?'

${ }^{3}$ Bryant, 'These Englands'; Bryant, The Nations of Britain; Colls, Identity of England; Russell, Looking North.

${ }^{4}$ Aughey, The Politics of Englishness; Crolley and Hand, Football, Europe and the Press; Crolley and Hand Football and European Identity; Maguire and Poulton, 'European Identity Politics in Euro 96'; Weight, Patriots.

${ }^{5}$ Perryman, Ingerland, 294.

${ }^{6}$ Carrington, 'Football's coming home but whose home?'; Carrington, 'Too many St. George Crosses to bear'; Garland and Rowe; Racism and Anti-Racism in Football.

${ }^{7}$ Weight Patriots, 708-10.

${ }^{8}$ Robinson 'Tackling the Anxieties of the English', 221, emphasis in original.

${ }_{9}^{9}$ Abell, Condor, Lowe, Gibson and Stevenson, 'Who Ate all the Pride?', 113.

${ }^{10}$ Maguire and Poulton, 'European Identity Politics in Euro 96'; Maguire, Poulton and Possamai, Weltkrieg III?'; Garland and Rowe, 'War Minus the Shooting?'

11 The G14 was the name given to a lobbying group consisting of some of the top European football clubs, including: Juventus; Liverpool; Real Madrid; Milan; Barcelona; Inter Milan; Bayern Munich; Ajax; Manchester United; PSV Eindhoven;
} 
Porto; Paris Saint-Germain; Marseilles; and, Borussia Dortmund, see King, The European Ritual, 152.

${ }^{12}$ Levermore and Millward, 'Official Policies and Informal Transversal Networks', 160.

${ }^{13}$ King, The European Ritual.

${ }_{14}$ Maguire, 'Globalization, sport and national identities', 991.

${ }^{15}$ King, The European Ritual; Maguire, 'Globalization, sport and national identities', 991.

${ }^{16} \mathrm{Homes}$ and Storey, 'Transferring national allegiance: cultural affinity or flag of convenience?', 266.

${ }^{17}$ Holmes and Storey, 'Who are the boys in green?', 89.

18 lbid., 101.

${ }^{19}$ Gibbons, 'Contrasting representations of Englishness during FIFA World Cup

Finals.'

${ }^{20}$ Millward, 'True Cosmopolitanism or Notional Acceptance of Non-national players in English football.'

${ }^{21}$ Ibid., 604.

22 King, The European Ritual; Millward, 'True Cosmopolitanism or Notional Acceptance of Non-national players in English football', 618, emphasis in original. ${ }^{23}$ Ibid.

${ }^{24}$ Maguire, 'Globalization, sport and national identities', 990.

${ }^{25}$ Aughey, The Politics of Englishness.

${ }^{26}$ At the time of writing Almunia still had never been called up to represent either the Spanish or English national squads. Capello resigned as England manager on 8 February 2012.

${ }^{27}$ In international football, unlike some other sports, FIFA's rules stipulate that players only have one choice of national team. Once they represent one national side they are no longer eligible to represent another nation.

${ }^{28}$ England did eventually qualify for the 2010 World Cup in early September 2009 after defeating Croatia 5-1 at Wembley.

${ }^{29}$ The term 'post' is used to refer to when someone makes a comment in an online discussion forum.

${ }^{30}$ The term 'thread' refers to a discussion thread in which topics are discussed by forum members by way of them 'posting' their responses.

${ }^{31}$ For more on using the internet for researching football fans see: Gibbons and Dixon, 'Surf's Up'; Gibbons and Nuttall, 'Using e-surveys to access the views of football fans within online communities.'

${ }^{32}$ Maguire and Poulton, 'European Identity Politics in Euro 96.'

${ }^{33}$ Miles and Huberman, Qualitative Data Analysis, 56.

34 lbid., 56.

${ }^{35}$ The date and time of each post appears before each extract.

${ }^{36}$ The numbers used at the beginning of each post extract indicate the code that has been used to protect the identity of the forum members. ' 1 ' is the number code used to refer to the author. The identity of fans has been protected by using their assigned number codes rather than the fan's actual screen-name. '(Fan 1)' has been used to keep the author's screen-name anonymous as it has the potential to lead to the identification of the forum used and thus the identities of members.

37 'tbh' is an abbreviation for the phrase 'to be honest'.

${ }^{38}$ King, The European Ritual; Levermore and Millward, 'Official Policies and Informal Transversal Networks'; Millward, "'We've all got the Bug for Euro-Aways."

${ }^{39}$ Maguire, 'Globalization, sport and national identities', 988.

${ }^{40}$ Maguire, Global Sport.

${ }^{41}$ This fan was referring to the Spanish centre-forward Fernando Torres who played for Liverpool between 2007 and 2011 (at the time of writing Torres plays for Chelsea). Torres was a prolific goal-scorer in his first and second seasons at Liverpool and fan 24 was alluding to this in his post. 
42 The term 'Johnny' is an abbreviation for 'Johnny foreigner' which is a person from a country other than those which make up the UK.

${ }^{43}$ Sven Goran Eriksson was the first non-British (Swedish) manager to lead the English national team.

44 ' $F T$ ' means full-time.

${ }^{45}$ Holmes and Storey, 'Transferring national allegiance'; Millward, 'True

Cosmopolitanism or Notional Acceptance of Non-national players in English football.'

${ }^{46}$ Maguire, 'Globalization, sport and national identities.'

47 'FFS' is an abbreviation for the phrase 'for fuck sake'.

48 'imo' is an abbreviation for the phrase 'in my opinion'.

${ }^{49}$ Crolley and Hand, Football and European Identity.

${ }^{50}$ Holmes and Storey, 'Who are the boys in green?'; Holmes and Storey,

'Transferring national allegiance'; Millward, 'True Cosmopolitanism or Notional

Acceptance of Non-national players in English football.'

${ }^{51}$ Maguire, 'Globalization, sport and national identities.'

${ }^{52}$ Giulianotti and Robertson, Globalization \& Football, 107.

${ }^{53}$ lbid., 109.

54 lbid., 110.

${ }^{55}$ Billig, Banal Nationalism; Giulianotti and Robertson, Globalization \& Football, 58.

${ }^{56}$ lbid., 58.

\section{References}

Abell, J., S. Condor, R.D. Lowe, S. Gibson, and C. Stevenson. 'Who Ate all the Pride?

Patriotic Sentiment and English Football Support'. Nations and Nationalism 13, no.1 (2007): 97-116.

Aughey, A. The Politics of Englishness. Manchester: Manchester University Press, 2007.

Billig, M. Banal Nationalism. London: Sage, 1995.

Bryant, C.G.A. 'These Englands, or Where Does Devolution Leave the English?'.

Nations and Nationalism 9, no. 3 (2003): 393-412.

Bryant, C.G.A. The Nations of Britain. Oxford: Oxford University Press, 2006. 
Carrington, B. 'Football's coming home but whose home? And do we want it? Nation, football and the politics of exclusion.' In Fanatics! Power, Identity and Fandom in Football, ed. A. Brown, 101-23. London: Routledge, 1998.

Carrington, B. (1999) 'Too many St. George Crosses to bear.' In The Ingerland Factor: Home Truths from Football, ed. M. Perryman, 71-86. Edinburgh: Mainstream, 1999.

Colley, L. Britons: Forging the Nation: 1707-1837. London: Vintage, 1996.

Colls, R. Identity of England. Oxford: Oxford University Press, 2002.

Crolley, L., and D. Hand. Football, Europe and the Press. London: Routledge, 2002.

Crolley, L., and D. Hand. Football and European Identity: Historical Narratives through the Press. London: Routledge, 2006.

Curtice, J. 'Is there an English Backlash? Reactions to Devolution'. In British Social Attitudes: The 25th Report, ed. A. Park, J. Curtice, K. Thomson, M. Phillips and E. Clery,1-23. London: Sage, 2009.

Garland, J. and Rowe, M. 'War Minus the Shooting? : Jingoism, the English Press, and Euro 96.' Journal of Sport and Social Issues 23, no.1 (1999): 80-95.

Garland, J. and Rowe, M. Racism and Anti-Racism in Football. Basingstoke: Palgrave, 2001.

Gibbons, T. 'Contrasting representations of Englishness during FIFA World Cup Finals.' Sport in History 30, no.3 (2010): 422-446. 
Gibbons, T. and Dixon, K. 'Surf's up! A call to take English soccer fan interactions on the Internet more seriously.' Soccer \& Society 11, no.5 (2010): 599-613.

Gibbons, T. and Nuttall, D. 'Using e-surveys to access the views of football fans within online communities.' Sport in Society 15, no.9 (2012): 1228-1241.

Giulianotti, R., and R. Robertson. Globalization \& Football. London: Sage, 2009.

Holmes, M. and Storey, D. 'Who are the boys in green? Irish identity and soccer in the Republic of Ireland.' In Sport and National Identity in the Post-WarWorld, eds. A. Smith and D. Porter, 88-104. London: Routledge, 2004.

Holmes, Michael and Storey, David. 'Transferring national allegiance: cultural affinity or flag of convenience?' Sport in Society 14, no.2 (2011): 253-71.

King, A. The European Ritual: Football in the New Europe. Aldershot: Ashgate, 2003.

King, A. 'Nationalism and Sport'. In The Sage Handbook of Nations and Nationalism, ed. G. Delanty and K. Kumar, 249-59. London: Sage, 2006.

Kumar, K. The Making of English National Identity. Cambridge: Cambridge University Press, 2003.

Levermore, R., and P. Millward. 'Official Policies and Informal Transversal Networks: Creating "Pan-European Identifications" Through Sport?' Sociological Review55, no.1 (2007):144-64. 
Maguire, J. and Poulton, E. 'European Identity Politics in Euro 96: Invented Traditions and National Habitus Codes.' International Review for the Sociology of Sport 34, no.1 (1999): 17-29.

Maguire, J., Poulton, E. and Possamai, C. 'Weltkrieg III? : Media Coverage of England Versus Germany in Euro 96.' Journal of Sport and Social Issues 23, no.4 (1999): 439_ 54.

Maguire, J. Global Sport: Identities, Societies, Civilizations. Cambridge: Polity, 1999.

Maguire, J. 'Globalization, sport and national identities'. Sport in Society 14, no.7/8 (2011): 978-93.

McCrone, D. 'Who do you say you are? Making sense of national identities in modern Britain.' Ethnicities 2, no.3 (2002): 301-20.

McCrone, D. 'A nation that dares not speak its name? The English question.' Ethnicities 6, no.2 (2006): 267-78.

Miles, M., and A. Huberman. Qualitative Data Analysis. Thousand Oaks, CA: Sage, 1994.

Millward, P. "We've all got the Bug for Euro-Aways": What Fans Say about European Football Club Competition'. International Review for the Sociology of Sport 41, no. 34 (2006): 375-93. 
Millward, P. ‘True Cosmopolitanism or Notional Acceptance of Non-national players in English football: Or, why 'bloody foreigners' get blamed when 'things go wrong'.' Sport in Society 10, no.4 (2007): 601-22.

Perryman, M. Ingerland: Travels with a Football Nation. London: Simon and Schuster, 2006.

Robinson, J.S.R. 'Tackling the Anxieties of the English: Searching For the Nation Through Football'. Soccer \& Society 9, no. 2 (2008): 215-30.

Russell, D. Looking North: Northern England and the National Imagination. Manchester: Manchester University Press, 2004.

Weight, R. Patriots: National Identity in Britain 1940-2000. London: MacMillan, 2002. 